\title{
Effect Of W/Cm Ratio And Superplasticiser Dosages On Stablity And Flowablity Of Self-Compacting Concrete
}

\author{
Nuha H. Al-Jubory
}

Assistant Lecturer

College of Engg./Civil Engg. Dept./ University of Mosul

\begin{abstract}
Self-compacting concrete (SCC) is a special concrete that does not require vibration for placing and compaction. It is able to flow under its own weight, completely filling formwork and achieving full compaction, even in the presence of congested reinforcement. The hardened concrete is dense, homogeneous and has the same engineering properties and durability as normal vibrated concrete.

The use of self-compacting concrete (SCC) is increasing every day in concrete industry due to its improving production techniques. However, mix design methods and testing procedures are still developing. The water/cement ratio and superplasticiser dosages were being one of the main key parameters in proportioning of SCC mixtures. In this study three mixtures with different combinations of water/cement ratio and superplasticiser dosage levels are investigated. Slump flow test is carried out to determine the effect of $\mathrm{w} / \mathrm{cm}$ and superplasticiser dosages on fresh and hardened properties of SCC that is bleeding, segregation, stability and compressive strength.

The results show that when w/cm increased from 0.32 to 0.36 , the flowability of SCC increased by $8.0 \%$ and $8.6 \%$ for superplasticiser dosages $1.8 \%$ and $2.2 \%$ respectively, and when w/cm increased from 0.36 to 0.4 , the flowability of SCC increased to $4.5 \%$ and $5.3 \%$ for the same levels of superplasticiser dosages.
\end{abstract}

Key words: Bleeding, Flowability, Segregations, Self-Compacting Concrete, Superplasticiser Dosage.

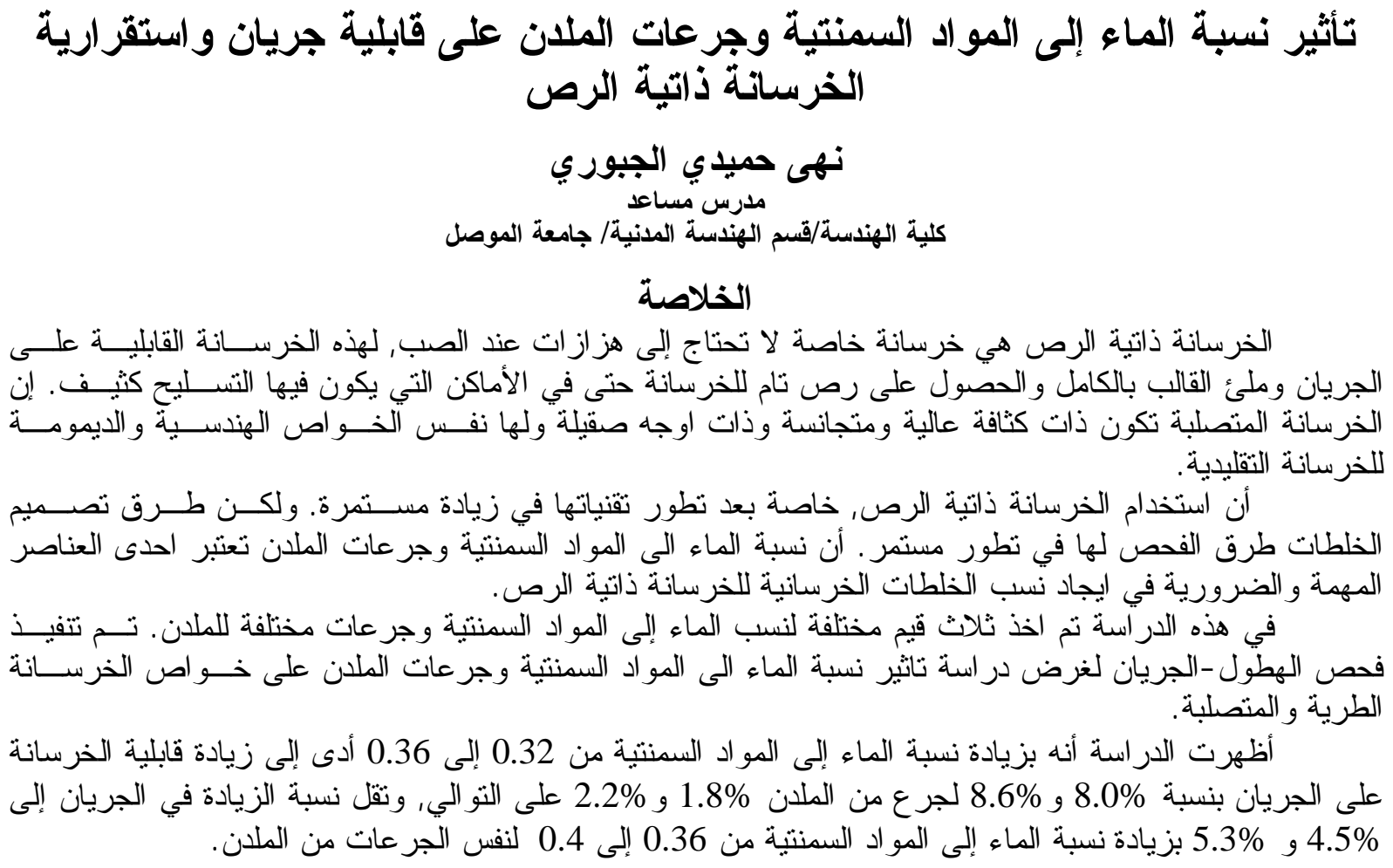




\section{$\begin{array}{llll}\text { Al-Rafidain Engineering } & \text { Vol.17 } & \text { No.1 } & \text { Feb. } 2009\end{array}$}

\section{Notations}

HRWRA high-range water-reducing admixture

SCC self compacting concrete

VSI visual stability index

w/c water to cement ratio

w/cm water to cementitious material (cement and filler) ratio

\section{Introduction}

Self-consolidating concrete (SCC) is a special type of concrete that can flow under its own weight without vibration, pass through intricate geometrical configurations, and resist segregation. The use of SCC can result in an increased construction productivity, improved jobsite safety, and improved concrete quality.

In response to the reduction in the skilled labor force in Japan's construction industry and the consequential reduction in the quality of construction, researchers at the University of Tokyo began developing self-consolidating concrete (SCC) in 1986.[1]

Ozawa et al.[2] authored the first paper on SCC in 1989, and Ozawa and other colleagues[3] presented a paper on the same subject at an international conference on concrete held in Istanbul in 1992. The presentation accelerated international interest in SCC. In 1998, the first international workshop on SCC was held in Kochi, Japan. Through efforts by Ozawa and his colleagues, more intensive research thrived, especially in large construction companies in Asia.

Hence, SCC was used in many structures, including buildings, bridge towers, and bridge girders.[1] Positive attributes of SCC include safety, reduced labor and construction time, and improved quality of the finished product.[1,4,5]

SCC is different than conventional concrete in that it has a lower viscosity and, thus, a greater flow rate when pumped. As a consequence, the pumping pressure is lower, reducing wear and tear on pumps and the need for cranes to deliver concrete in buckets at the job site.[6]

To achieve a high workability and avoid obstruction by closely spaced reinforcing bars, SCC is designed with limits on the nominal maximum size (NMS) of the aggregate, the mount of aggregate, and aggregate grading. However, when the workability is high, the potential for segregation and loss of entrained air voids increases. These problems can be alleviated by designing a concrete with a high fine-to-coarse-aggregate ratio, a low watercementitious material ratio $(\mathrm{w} / \mathrm{cm})$, good aggregate grading, and a high-range water-reducing admixture (HRWRA) [7]. However, care should be exercised when a high fine-to-coarse aggregate ratio is used since shrinkage would increase. Viscosity modifying admixtures (VMA) are also used to reduce the tendency for segregation and enhance the stability of the air-void system.[8,9]

A potentially negative aspect of SCC is shrinkage. Since generally a large amount of fine material is used in the mixtures (particularly those without VMA) and the NMS is limited, the concrete typically has higher shrinkage. Increased shrinkage may result in more cracks in restrained concrete elements, which can accelerate the deterioration of both the concrete and the reinforcement.

\section{Purpose and Scope}

The purpose of this work is to develop and evaluate some properties of SCC made with locally available materials, including the effect of w/cm ratio and superplasticiser dosages on flowablity, segregation and compressive strength of SCC. 


\section{Materials:}

Cement: One type of cement was used, Ordinary Portland Cement, produced locally in accordance with Iraqi Specification (IQS. No.5,1985)[10]. The physical and chemical properties are given in table (1) and (2) respectively.

Table (1) : Chemical Composition of The O.P.C.

\begin{tabular}{|c|c|c|}
\hline Property & Test result (Percentage) & Standard IQS, No.5 \\
\hline 1.Oxide composition: & 4.7 & - \\
\hline Alumina, $\mathrm{Al}_{2} \mathrm{O}_{3}$ & 21.5 & - \\
\hline Silica, $\mathrm{SiO}_{2}$ & 2.41 & - \\
\hline Ferric Oxide, $\mathrm{Fe}_{2} \mathrm{O}_{3}$ & 62.86 & Max. 3 \\
\hline Lime, $\mathrm{CaO}$ & 3.02 & Max. 4 \\
\hline Sulphuric Anhydride, $\mathrm{SO}_{3}$ & 2.25 & Min. 5 \\
\hline Magnesia, MgO & & - \\
\hline 2.Compound composition: & 8.4 & - \\
\hline $\mathrm{C}_{3} \mathrm{~A}$ & 27.18 & - \\
\hline $\mathrm{C}_{2} \mathrm{~S}$ & 46.14 & \\
\hline $\mathrm{C}_{3} \mathrm{~S}$ & 7.3 & \\
\hline $\mathrm{C}_{4} \mathrm{AF}$ & & \\
\hline
\end{tabular}

Table (2) : Physical Properties of The O.P.C.

\begin{tabular}{|c|c|c|}
\hline Property & Test result & Standard IQS, No.5 \\
\hline Fineness(Residue on sieve No. 170) & & Max. 10\% \\
\hline Specific surface "Blaine"(cm $2 / \mathrm{gm})$ & 3358.5 & Min. 2250 \\
\hline Initial setting time & 150 (min.) & 60 (min.) \\
\hline Final setting time & 215 (min.) & 600 (max.) \\
\hline Specific gravity & 3.14 & \\
\hline Compressive strength (MPa) & & \\
\hline at 3 days & 21.4 & 16.0 (min.) \\
\hline at 7 days & 36 & 24.0 (max.) \\
\hline
\end{tabular}

Fine aggregate: Medium sand in accordance with British Standards (B.S.) 882:1983[11] was used in this investigation. Its main properties and sieve analysis are listed in tables (3) and (4) respectively.

Table (3) : Relative Properties of Fine Aggregate

\begin{tabular}{|c|c|c|c|c|c|c|}
\hline $\begin{array}{c}\text { Type of } \\
\text { fine } \\
\text { aggregate }\end{array}$ & Color & \multicolumn{2}{|c|}{$\begin{array}{c}\text { Specific } \\
\text { Gravity }\end{array}$} & $\begin{array}{c}\text { Absorption } \\
\%\end{array}$ & $\begin{array}{c}\text { Compact } \\
\text { unit weight } \\
\left(\mathbf{K g} / \mathbf{m}^{\mathbf{3}}\right)\end{array}$ & $\begin{array}{c}\text { Loose unit } \\
\mathbf{w e i g h t} \\
\left(\mathbf{K g} / \mathbf{m}^{3}\right)\end{array}$ \\
\hline $\begin{array}{c}\text { Medium } \\
\text { sand }\end{array}$ & \multirow{2}{*}{ Brown } & $\begin{array}{c}\text { Oven } \\
\text { dry basis }\end{array}$ & $\begin{array}{c}\text { S.S.D } \\
\text { basis }\end{array}$ & 1 & 1939 & 1883 \\
\cline { 2 - 6 } & 2.38 & 2.36 & & & \\
\hline
\end{tabular}


Table (4) : Sieve Analysis of Fine Aggregate

\begin{tabular}{|c|c|c|}
\hline $\begin{array}{c}\text { Sieve Size } \\
(\mathbf{m m})\end{array}$ & $\begin{array}{c}\text { British Specifications } \\
\text { limits\%passing }\end{array}$ & \%passing \\
\hline 4.75 & $89-100$ & 91.5 \\
\hline 2.36 & $65-100$ & 74 \\
\hline 1.18 & $45-100$ & 61 \\
\hline 0.6 & $25-80$ & 44 \\
\hline 0.3 & $5-48$ & 12.5 \\
\hline 0.15 & $0-15$ & 3 \\
\hline \multicolumn{2}{|l}{ Fineness Modulus 3.14 } \\
\hline
\end{tabular}

Coarse aggregate: Coarse aggregate used were normal river gravel (irregular almost rounded maximum aggregate size 14mm) in accordance with B.S 882(1983)[11]. Their physical properties are given in table(5), while their sieve analysis and grading are given in table(6).

Table (5): Relative Properties of Coarse Aggregate

\begin{tabular}{|c|c|c|c|c|c|}
\hline $\begin{array}{c}\text { Type of } \\
\text { coarse } \\
\text { aggregate }\end{array}$ & $\begin{array}{c}\text { Maximum } \\
\text { aggregate } \\
\text { size (mm) }\end{array}$ & $\begin{array}{c}\text { Specific } \\
\text { Gravity } \\
\text { S.S.D }\end{array}$ & $\begin{array}{c}\text { Absorption } \\
\%\end{array}$ & $\begin{array}{c}\text { Compact } \\
\text { unit weight } \\
\left(\mathbf{K g} / \mathbf{m}^{\mathbf{3}}\right)\end{array}$ & $\begin{array}{c}\text { Loose unit } \\
\text { weight } \\
\left(\mathbf{K g} / \mathbf{m}^{3}\right)\end{array}$ \\
\hline $\begin{array}{c}\text { Rounded } \\
\text { gravel }\end{array}$ & 10 & 2.7 & 0.5 & 1742 & 1656 \\
\hline
\end{tabular}

Table (6): Sieve Analysis of Coarse Aggregate

\begin{tabular}{|c|c|c|}
\hline Sieve Size(mm) & $\begin{array}{c}\text { British Specifications } \\
\text { limits \%passing }\end{array}$ & \%passing \\
\hline 20 & 100 & 100 \\
\hline 14 & $90-100$ & 94.4 \\
\hline 10 & $50-85$ & 55.4 \\
\hline 5 & $0-10$ & 6.4 \\
\hline \multicolumn{2}{|l}{} \\
\hline
\end{tabular}

Mixing Water: Ordinary drinking (tap) water was used for concrete mixes.

Filler Material: Limestone powder $\left(\mathrm{CaCo}_{3}\right)$ is used as a filler material, the particles passing sieve No. 100 (0.150 mm).

Chemical Admixture: Sikament-NN is a high range water reducing (HRWR). It is used to meet the necessary workability, stability and flowability. The main properties are shown in table (7).

Table (7): The Properties of HRWR

\begin{tabular}{|c|l|}
\hline Type & Naphthalene formaldehyde sulphonate \\
\hline Colour & Dark brown \\
\hline Density & $1.2 \mathrm{~kg} / 1$ \\
\hline Dosage & $\begin{array}{l}0.8-3 \% \text { by weight of cement depending on } \\
\text { desired workability and strength }\end{array}$ \\
\hline
\end{tabular}




\section{Mix Proportions}

The investigated mixes were prepared with three different $\mathrm{w} / \mathrm{cm}$ of $0.32,0.36$, and 0.40. An increase in $\mathrm{w} / \mathrm{cm}$ resulted in an increase in paste volume because the binder content was kept constant at $480 \mathrm{~kg} / \mathrm{m} 3$ (Table 8), the control mix was designed by ACI method [12]. The sand-to-total aggregate ratio (by volume) remained constant at 0.49 for all of the tested mixes. The superplasticiser was added in different dosages to study its effect on bleeding and segregation. The limestone powder was $20 \%$ of cementitious materials weight [13].

Table (8) Mix Proportions of Investigated Concretes

\begin{tabular}{|l|c|c|c|}
\hline \multicolumn{1}{|c|}{ mix } & $\mathbf{1}$ & $\mathbf{2}$ & $\mathbf{3}$ \\
\hline Cement, $\mathrm{kg} / \mathrm{m}^{3}$ & 384 & 384 & 384 \\
\hline Limestone Powder $\mathrm{kg} / \mathrm{m}^{3}$ & 96 & 96 & 96 \\
\hline Coarse aggregate $\mathrm{kg} / \mathrm{m}^{3}$ & 890 & 860 & 830 \\
\hline Sand, $\mathrm{kg} / \mathrm{m}^{3}$ & 940 & 910 & 875 \\
\hline Water, $\mathrm{kg} / \mathrm{m}^{3}$ & 153 & 173 & 210 \\
\hline w/cm ratio & 0.32 & 0.36 & 0.40 \\
\hline \% of Paste Volume & 62.8 & 63.8 & 64.7 \\
\hline \% of Total aggregate volume & 67.11 & 65.15 & 63.29 \\
\hline
\end{tabular}

\section{Mix Procedure}

All mixes were prepared in an open pan. The mixing sequence consisted of homogenizing the coarse and fine aggregates for one minute before introducing part of the mixing water. After one minute of mixing, cementitious materials (cement and limestone powder) were added, and the mixture was mixed for a further three minutes. Then HRWR and remaining part of water were added. After that, the concrete was allowed to rest for three minutes to allow the admixtures to initiate. At the end of the rest, the concrete was remixed for two additional minutes[14].

Once, the mix was determined to have sufficient visual attributes of SCC, the rheological (workability) tests were performed in quick succession.

\section{Slump flow test}

Slump flow tests, [12] are used to determine flowability and stability of self compacting concrete. The equipment consists of a slump cone, a flow table shown in Fig(1). A concentric diameter of $500 \mathrm{~mm}$ is marked on the table. The slump cone is filled with concrete while holding the slump cone steady to the table. Next, the slump cone is lifted vertically and time measurement is started. Time for concrete diameter to reach $500 \mathrm{~mm}$ (T50) is recorded. When the concrete has stopped flowing, the final diameter (D-final) of the concrete and if necessary any segregation border at the concrete periphery is measured, see Fig(1)

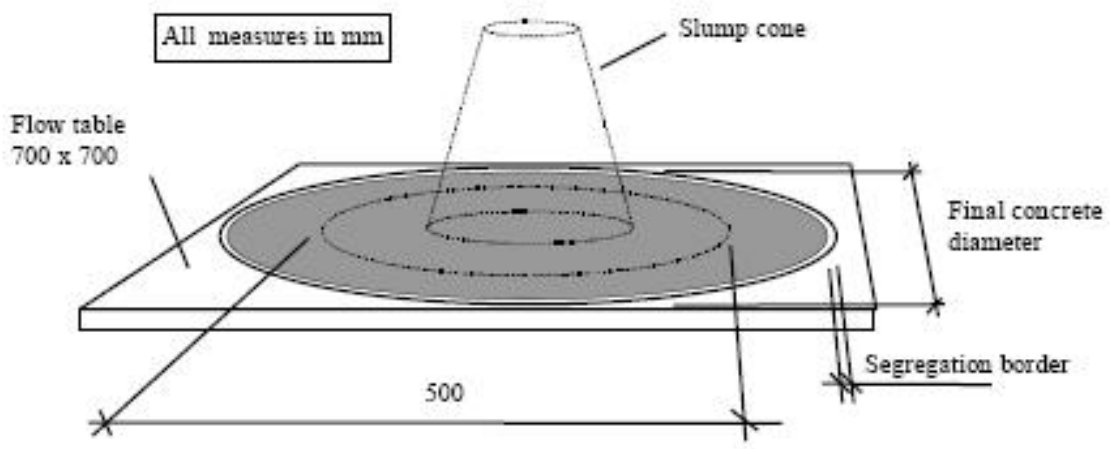

Fig. (1) The Slump Flow Test 


\section{Criteria for slump-flow and T50}

Structural SCC favors for strength and durability reasons a lower w/cm around 0.40 . In this case the criteria can depend on the total amount of fines and of course the w/cm. When the amount of filler and cement is as high as $550-600 \mathrm{~kg} / \mathrm{m}^{3}$ it can permit slump-flow to reach between $670-730 \mathrm{~mm}$. Otherwise the criteria $600-700 \mathrm{~mm}$ is normally valid. Maybe $600 \mathrm{~mm}$ can be too low in some cases. If the precision in production is high the criteria can be 650-700 $\mathrm{mm}$ because the optimum slump-flow is around $700 \mathrm{~mm}$. When casting horizontal constructions the target value for slump-flow is lower than for vertical constructions if a finishing device is used or a slope should be constructed. T50 is varying dependent on $\mathrm{w} / \mathrm{cm}$. For vertical constructions SCC with slump-flow of $700 \mathrm{~mm}$, T50 can be around 4 seconds. For horizontal constructions SCC with slump-flow of $650 \mathrm{~mm}$, T50 can be around 7 seconds. In house construction SCC has a relatively high w/cm. The slump-flow value should reach between $600-700 \mathrm{~mm}$. Over $700 \mathrm{~mm}$ the risk for coarse aggregate segregation is high, at least when only filler is used to control the viscosity of paste. T50 can be lower than 4 seconds for structural SCC (depending on admixture) [13].

\section{Concrete visual stability index}

After the flow test was conducted, Concrete's visual stability index (VSI) was determined [12]. The criteria used for VSI rating is described in table (9).

\section{Table (9) visual stability index (VSI) rating criteria}

\begin{tabular}{|c|l|}
\hline VSI & \multicolumn{1}{|c|}{ criteria } \\
\hline 0 & $\begin{array}{l}\text { No evidence of segregation in slump flow patty, mixer drum or wheel } \\
\text { barrow }\end{array}$ \\
\hline 1 & $\begin{array}{l}\text { No mortar halo in slump flow patty, but some bleeding on the surface of } \\
\text { concrete mix drum or wheel barrow. }\end{array}$ \\
\hline 2 & $\begin{array}{l}\text { A slight mortar halo }(<3 / 8 \text { in }(10 \mathrm{~mm}) \text { ) in slump patty and noticeable } \\
\text { layer of mortar on the surface of resting concrete in mixer. }\end{array}$ \\
\hline 3 & $\begin{array}{l}\text { Clearly segregation by evidence of large mortar halo }(>3 / 8 \text { in }(10 \mathrm{~mm})) \\
\text { and a thick layer of mortar and bleed water in the surface of resting } \\
\text { concrete. }\end{array}$ \\
\hline
\end{tabular}

\section{Test Results And Discussion \\ Fresh Concrete Properties}

The properties of the tested SCC in its fresh state are summarized in Table (10). All mixtures exhibited proper flowability, particularly in the case of those made with higher values of w/cm, and the same dosage of superplasticiser Figs.(2), (3) and (4). An increase in $w / \mathrm{cm}$, or paste volume, resulting in lower coarse aggregate volume, table (8), can reduce the degree of internal friction, thus increasing the ability of concrete to flow as shown in Fig.(5).

\section{Relationship between Superplasticiser Dosage and Flowability}

The relationship determined between flow and superplasticiser dosages shown in Fig (2). The results show that for each w/cm ratio, (for the flow range from 500 to $700 \mathrm{~mm}$ ), the superplasticiser dosages were near $1.5 \%$ to $2.2 \%$ for these mixes proportions. This range was the effective dosage. When less than $1.5 \%$ superplasticiser dosage was used, the concrete didn't have flowability and when a superplasticiser dosage greater than $2.2 \%$ was used, the flow remained constant, indicating that there is a superplasticiser saturation dosage. The two dosages $1.8 \%$ and $2.2 \%$ (within the effective dosage) were used to study the effect on flow 
and strength. Fig.(3) shows the flow of one mix with two different of superplasticiser dosages, when superplasticiser dosage increased, the flow increased.

A cementitious material becomes more fluid when a superplasticiser is added at a certain dosage limit but the effect is negligible for higher dosages. This certain dosage is defined as the saturation dosage of the superplasticiser for the considered powder. It is generally expressed as the ratio (in percentage) between the mass of dry extract of the superplasticiser and the mass of the powder.

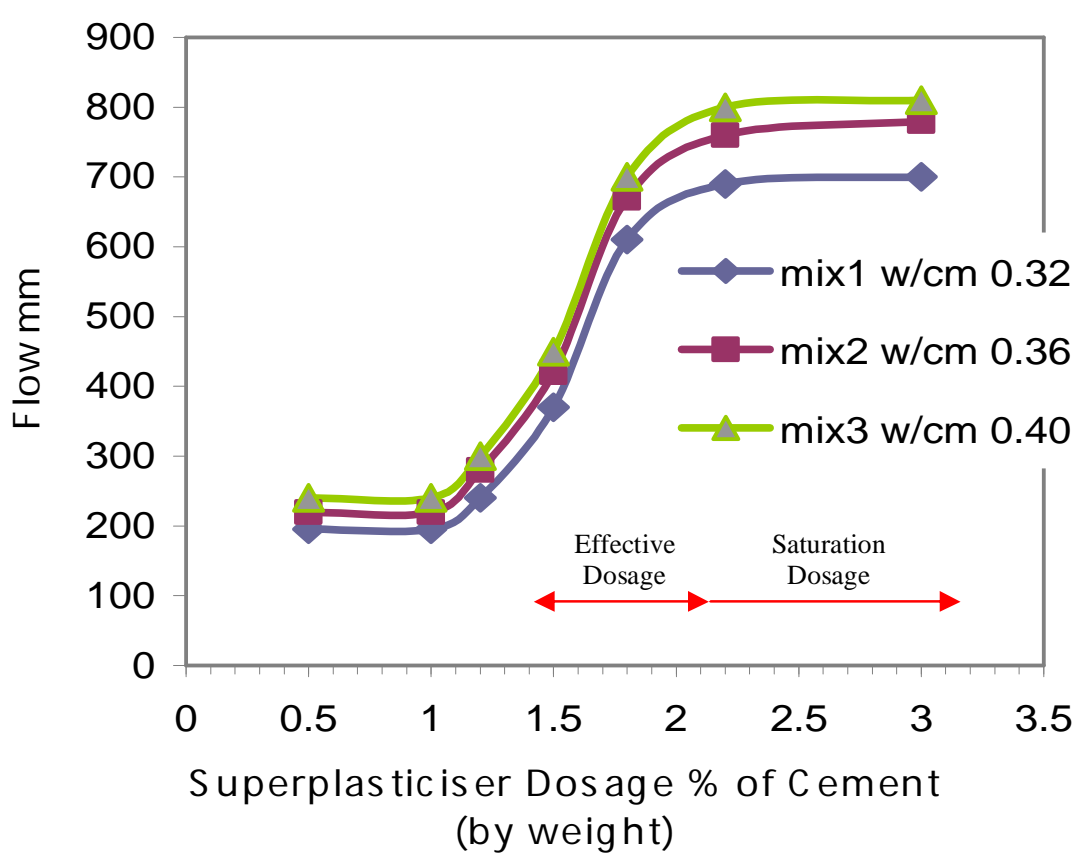

Fig.(2) The Relation between Flow and Superplasticiser Dosages

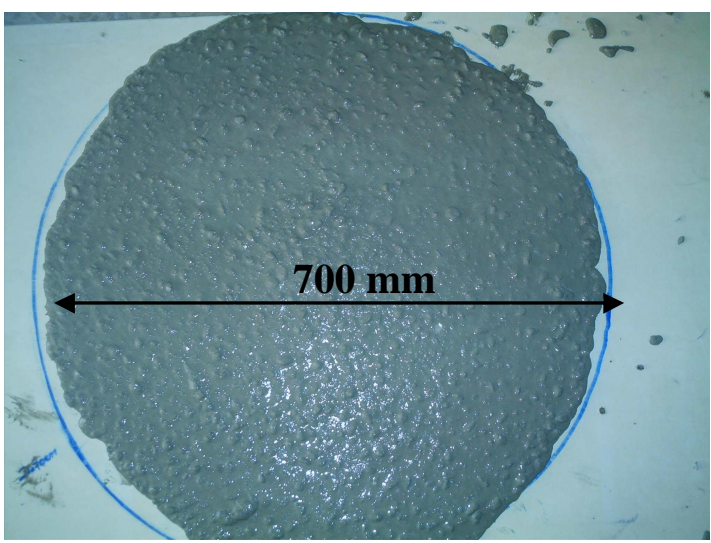

A) superplasticiser dosage $=2.2 \%$

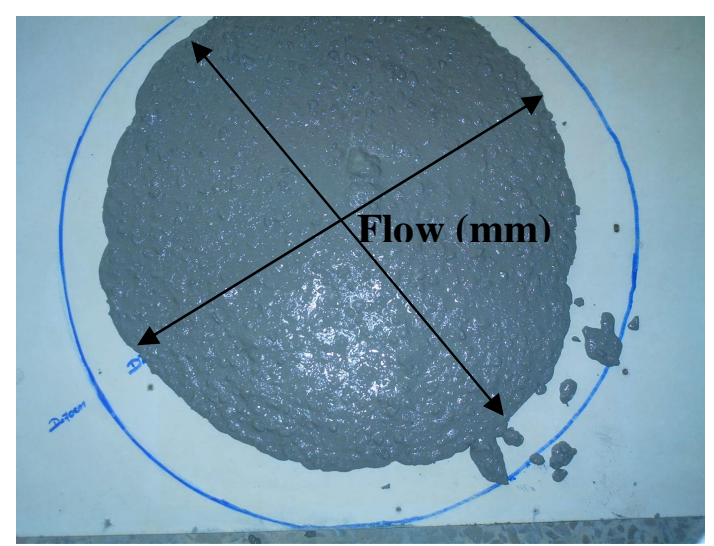

B) superplasticiser dosage $=1.8 \%$

Fig.(3) The Flow of Mix in Slump-Flow Test 


\section{$\begin{array}{llll}\text { Al-Rafidain Engineering } & \text { Vol.17 } & \text { No.1 } & \text { Feb. } 2009\end{array}$}

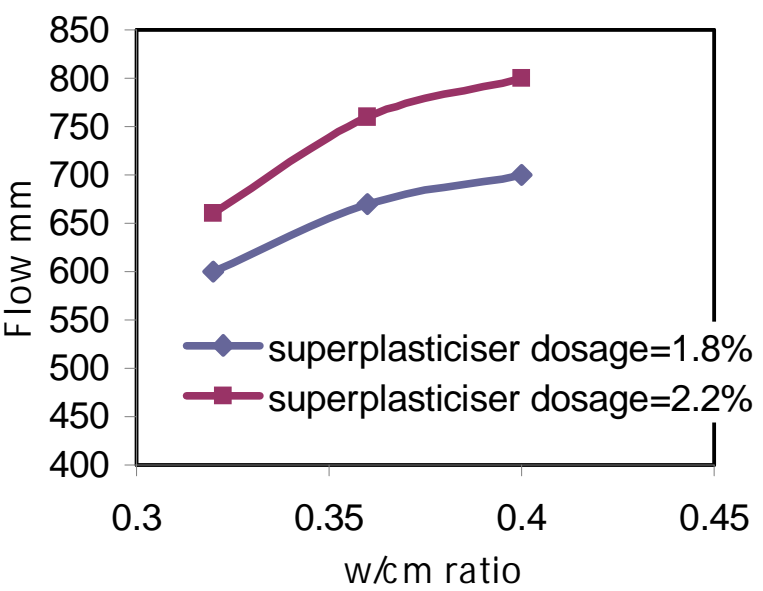

Fig.(4) The Relation between Flow and Water Cementitious Material Ratio

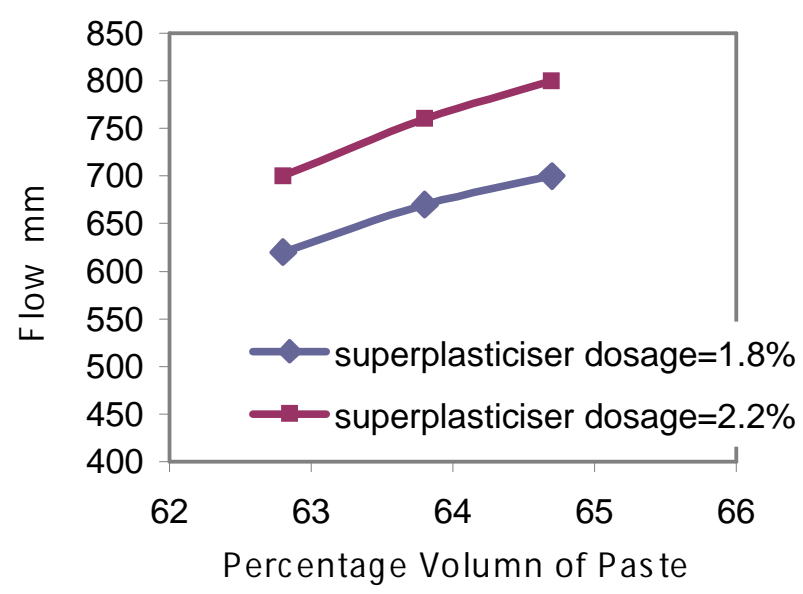

Fig.(5) The Relation between Flow and $\%$ Volume of Paste

\section{Relationship between Concrete visual stability index and w/cm Ratio}

Concrete visual stability index (VSI) depends essentially on water cement ratio, from table (10) an increase in $w / \mathrm{cm}$ ratio, resulting in an increase in the (VSI). Generally, in mixtures prepared with low water cement ratio of 0.32 , there was no evidence of segregation, but when w/cm ratio increased some bleeding was noticed on the surface of concrete. At high w/cm ratio of 0.4 there was a layer of mortar on the surface of resulting concrete in mixer.

Table (10) Fresh properties of the tested SCC

\begin{tabular}{|c|c|c|c|c|c|c|}
\hline Mix & \multicolumn{2}{|c|}{1} & \multicolumn{2}{c|}{2} & \multicolumn{2}{c|}{3} \\
\hline w/cm & \multicolumn{2}{|c|}{0.32} & \multicolumn{2}{c|}{0.36} & \multicolumn{2}{c|}{0.40} \\
\hline Superplasticiser dosage & $1.8 \%$ & $2.2 \%$ & $1.8 \%$ & $2.2 \%$ & $1.8 \%$ & $2.2 \%$ \\
\hline Flow (mm) & 620 & 700 & 670 & 760 & 700 & 800 \\
\hline T50 (sec) & 4.67 & 3.31 & 3.0 & 2.8 & 2.7 & 2.6 \\
\hline VSI & 0 & 0 & 1 & 1 & 2 & 2 \\
\hline
\end{tabular}

\section{Properties of Compressive Strength}

For compressive strength test used $100 \mathrm{~mm} * 100 \mathrm{~mm} * 100 \mathrm{~mm}$ cube, the specimens were cured (in water for 28 day) and tested according to BS 1881 parts 108, 111, and 116 [15].

Fig (6) shows that the relation between age and compressive strength of SCC, for different water-cement ratio; It is noticed that the rate of increase at early ages is more pronounced than that at later ages. also the Fig(6) indicates that a lower percentage of superplasticiser dosage $(1.8 \%)$ gives a higher strength than that of $(2.2 \%)$ especially at higher w/cm ratios. 

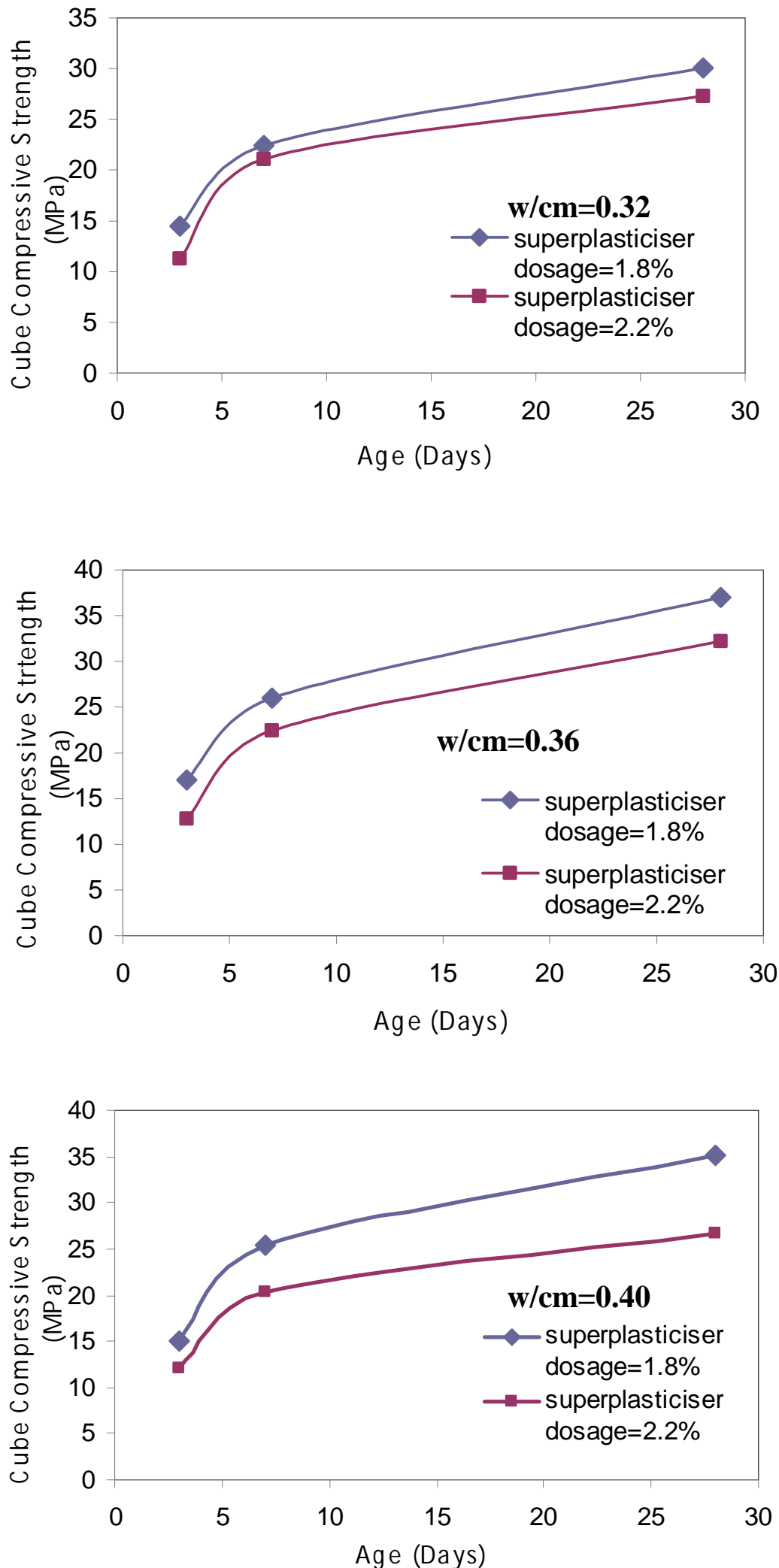

Fig.(6)The Relation between Cube Compressive Strength and Age of Curing 


\section{Conclusions}

Based on the results of this study, the following conclusions can be drawn:-

1. Flowability of SCC made with locally available materials increased as the $w / \mathrm{cm}$ ratio increased at the same level of superplasticiser dosages.

2. The results indicated that an effective range of superplasticiser dosages causing an increase in the workability of SCC.

3. Flowability of SCC doesn't improve significantly when superplasticiser saturation dosage is reached.

4. Resistance to segregation can be improved by minimizing the free water to avoid bleeding.

5. The rate of increase of compressive strength at early ages is more pronounced than that at later ages. also results indicated that a lower percentage of superplasticiser $(1.8 \%)$ gives a higher strength than that of $(2.2 \%)$ especially at higher w/cm ratios.

\section{References}

1. Okamura, H., and M. Ouchi. "Self-Compacting Concrete: Development, Present Use and Future". In Self Compacting Concrete: Proceedings of the First International RILEM Symposium, A. Skarendahl, and O. Petersson, Eds. RILEM Publications, Cachan Cedex, France, 1999, pp. 3-14.

2. Ozawa, K., K. Maekawa, M. Kunishima, and H. Okamura. "Development of High Performance Concrete Based on the Durability Design of Concrete Structures". In Proceedings of the Second East-Asia and Pacific Conference on Structural Engineering and Construction (EASEC-2), Vol. 1, pp. 445-450, January 1989.

3. Ozawa, K., S. Tagtermsirikul, and K. Maekawa. "Role of Materials on the Filling Capacity of Fresh Concrete". In Proceedings of the Fourth CANMET and ACI International Conference on Fly Ash, Silica Fume, Slag and Natural Pozzolans in Concrete, American Concrete Institute, May 1992, pp. 212-137.

4. Grauers, M. "Self Compacting Concrete: Industrialized Site Cast Concrete". In Proceedings of the First International RILEM Symposium. Swedish Cement and Concrete Research Institute, Stockholm, Sweden, 1999, pp. 651-658.

5. Bickley, J., K.H. Khayat, and M. Lessard. "Performance of Self-Consolidating Concrete for Casting Basement and Foundation Walls". ACI Materials Journal, Title No. 97-M44, MayJune 2000, pp. 374-380.

6. Khayat, K.H., C. Hu, and H. Monty. "Stability of Self-Consolidating Concrete", Advantages, and Potential Applications. In Self Compacting Concrete: Proceedings of the First International RILEM Symposium, A. Skarendahl, and O. Petersson, Eds. RILEM Publications, Cachan Cedex, France, 1999, pp. 143-152.

7. Okamura, H., and K. Ozawa. "Mix-Design for Self-Compacting Concrete". Concrete Library of the Japanese Society of Civil Engineers, No. 25, June 1995, pp. 107-120.

8. Khayat, K.H. "Use of Viscosity-Modifying Admixture to Reduce Top-Bar Effect of Anchored Bars Cast with Fluid Concrete". ACI Materials Journal, Vol. 95, No. 2, 1998, pp.158-167. 


\section{Al-Jubory: Effect Of W/Cm Ratio And Superplasticiser Dosages On Stablity}

9. Khayat, K.H., and J. Assaad. "Air-void Stability in Self Consolidating Concrete". $A C I$ Materials Journal, Vol. 99, No. 4 , 2002, pp. 408-416.

$$
\text { 10. المواصفة القياسية العراقية رقم (5) لسنة } 1985 \text { (السمنت البورتلاندي) }
$$

11. B.S. 882-1983, "British Standard Specification for Aggregate from Natural Sources for Concrete", 1983.

12. Ashok H. Gurjar Report No. BD 503. "Mix Design and Testing of Self-Compacting Concrete Using Florida Materials", December 2004, 111pp.

13. Final reports from Task 2: Workability, Ö. Petersson, Swedish Cement and Concrete Research Institute, 1999.

14. Kamal H. Khayat and Joseph J. Assaad, "Effect of w/cm and High-Range WaterReducing Admixture on Formwork Pressure and Thixotropy of Self-Consolidating Concrete". ACI Materials Journal, Vol. 103, No. 3 , 2006, pp. 186-193.

15. British Standards BSI, "Methods for Making Test Cubes from Fresh Concrete", " Methods for Normal Curing of Test Specimens", and "Methods for Determination of Compressive strength Concrete Cubes", Parts 108, 111, and 116 respectively 1999. 